\title{
Discussions de la 3ème partie
}

\section{(2) OpenEdition \\ 12 Journals}

Édition électronique

URL : https://journals.openedition.org/tc/625

DOI : $10.4000 /$ tc. 625

ISSN : 1952-420X

Éditeur

Éditions de l'EHESS

\section{Édition imprimée}

Date de publication : 1 septembre 1994

ISSN : 0248-6016

\section{Référence électronique}

"Discussions de la 3ème partie », Techniques \& Culture [En ligne], 21 | 1994, mis en ligne le 30

décembre 2005, consulté le 29 septembre 2022. URL : http://journals.openedition.org/tc/625 ; DOI :

https://doi.org/10.4000/tc.625

Ce document a été généré automatiquement le 29 septembre 2022.

Tous droits réservés 


\section{Discussions de la 3ème partie}

